\section{Deep sea research}

\section{Watery grave?}

\section{Washington}

In a compromise designed to meet conflicting pressures on oceanographic research, the National Science Foundation (NSF) has decided to incorporate its current Deep Sea Drilling Project (DSDP) into its new Ocean Margin Drilling Program (OMDP), the latter to be financed jointly with the oil industry using the drilling ship Glomar Explorer to investigate the geology of the ocean bed.

The decision will mean phasing out Glomar Challenger, the ship from which DSDP currently operates. Several scientific goals of the programmes will continue in drilling from the Explorer. To accommodate them, part of Explorer's own research programme, to be directed at the ocean margins beyond the edge of the continental shelf, will be delayed.

NSF officials hope that by combining the two programmes they will significantly reduce the total costs of scientific ocean drilling programmes and provide a "realistic framework" within which both can be pursued. In addition to the financial advantages, they concede that the decision should reduce some of the friction that had been caused by the scientific community's concern that commercial goals would squeeze out scientific objectives.

Ten oil companies have so far agreed in principle to contribute towards the costs of the Ocean Margin Drilling Program, announced last year by NSF as a jointlyfunded venture (Nature 283, 321; 1980). The project had been enthusiastically promoted by the Office of Science and Technology Policy as a model for future collaboration between the public and the private sector.

Many scientists, however, feared that too much of the OMDP activity would be concentrated on areas of the ocean floor of greater interest to the oil industry than to the academic community; also that the series of experiments currently being conducted from Glomar Challenger, which can drill holes more cheaply and quickly but is more restricted in its performance, than Glomar Explorer, would be brought to a premature conclusion.

Dr John Slaughter, director of NSF, has now announced a compromise. Glomar Challenger will be retired in about 1983, when experiments would be transferred to Explorer. Plans to equip Explorer with a "riser" - a casing around the drill used to prevent blow-outs from occurring if pockets of oil or gas are hit - would be carried out 2 or 3 years later. After that the Explorer would divide its time between OMDP (to which industry will contribute about $\$ 18$ million a year) and an extension of the current non-riser drilling being carried out by Challenger, a solution which seems acceptable to both scientists and industry representatives. David Dickson

\title{
A Press Council adjudication
}

This is the text of an adjudication issued by the UK Press Council on 26 August:

The Press Council finds the author was invited to submit an article but not that there was an undertaking that the article would be published. Notwithstanding the invitation, whether it would be published remained a matter for the editor's decision. Alterations which met the criteria laid down by the editor had not been made by the time he told Dr Miller he had decided after all not to publish the article and suggested he send it elsewhere.

The editor did, as Dr Miller complains, submit the article to another scientist mentioned in it, but the Press Council is satisfied he did so with Dr Miller's consent and no complaint can be made at this.

The council is not satisfied the editor used material from the unpublished article in his editorial comment dealing with the same subject. The council, however, believes that the timing of the editorial comment so soon after the rejection of the article was unfortunate. It shares the view put to it by the editor that he ought to have given Dr Miller a fuller answer sooner - and thus an opportunity to submit his article to another scientific journal for consideration before publication of Nature's editorial on the subject. The complaint against Nature is not upheld.

The explanatory statement issued by the UK Press Council is as follows:

Although a scientist was invited to submit a magazine article, the decision whether to publish it was for the editor, the Press Council has ruled.

Soon after an invited article was rejected, the magazine commented editorially on the same subject. Despite the unfortunate timing, the Press Council said, it was not satisfied the editor used material from the submitted article.

The council did not uphold a complaint against Nature by Dr Jeffrey H. Miller, professor in the Department of Molecular Biology at the University of Geneva that, having refused to publish an invited article submitted to him in confidence and amended by the author according to requirements stipulated by the editor, the editor submitted the article to a person mentioned in it and used some of the material in the article as the basis of his own editorial comment.

Dr Miller suggested an article to Nature and was asked to submit it. In it he forecast growing controversy over mixed industrial and academic research into applied microbiology. The article contained criticisms of Professor Charles Weissmann, of the University of Zurich.

Mr John Maddox, who then became editor of Nature, sent Dr Miller an amended copy of the manuscript, saying charges against individual scientists should be justifiable and temperate. Dr Miller sent a second version including many suggested changes but which was still critical of Professor Weissmann.

The editor phoned Dr Miller saying he was ready to publish the article but would like to show it to Professor Weissmann. Dr Miller gave permission. Mr Maddox later said he could not publish the article: it was too directly concerned with Professor Weissmann's work.

Dr Miller then sent a third version, saying he had agreed to the professor seeing the article because he assumed it was agreed in principle to publish it. Although he asked for an explanation if the article was not published, he did not receive one.

Soon afterwards Nature commented editorially on the propriety of academics being involved with commercial interests, saying attempts to exploit new genetic manipulation techniques could sour the atmosphere of academic research.

After the solicitors for Dr Miller complained to the Press Council, the editor said it was a convention of the scientific press that personal criticism by outside contributors was not published without warning. He would have replied to $\mathrm{Dr}$ Miller if the latter had not told a colleague that he would complain to the council if his third draft were not published.

Dr Miller said the editor's plagiarism of themes not before similarly expressed made it difficult to publish his article elsewhere. Mr Maddox argued that Dr Miller's comment covered the whole academic community while the leading article dealt primarily with molecular biology.

Mr Maddox said there were incorrect and unpublishable charges against Professor Weissmann in the first version. He had had two long phone conversations with $\mathrm{Dr}$ Miller. In the second he said he would publish the article if the professor could see it. Discovering that Professor Weissmann acted with propriety had undermined his confidence in Dr Miller's reporting.

Dr Miller commented he had understood the article was accepted for publication and only the Weissmann references were in doubt. The reasons given for withdrawal had no substance and the editor drew heavily on his article.

Dr Miller could not attend an oral inquiry. Mr Maddox told the complaints committee he showed the second version to Professor Weissmann, who explained he had a formal agreement regulating his commercial activities. This was not mentioned in Dr Miller's drafts. $\mathrm{Mr}$ Maddox said that his reaction to the third draft was that Dr Miller could have made the amendments earlier but that on reflection he regretted his rather hottempered reaction that there was no point in further correspondence.

Nature has no further comment to make except to hope that Dr Miller (and Professor Weissmann) will continue to contribute to its columns. 